
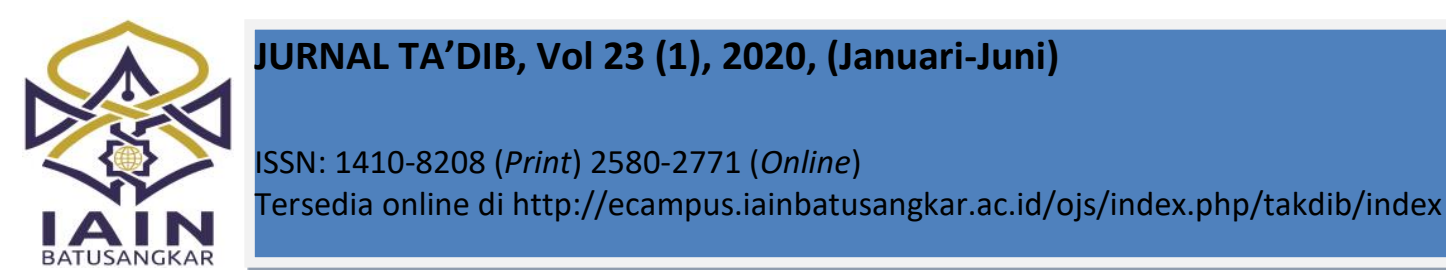

\title{
Model Pengembangan Kecerdasan Spiritual dalam Pembelajaran Akhlak di Pesantren Modern Indonesia
}

\author{
Arlina*) \\ Universitas Islam Negeri Sumatera Utara, \\ Indonesia \\ E-mail: arlina@uinsu.ac.id
}

\section{Didik Santoso}

Universitas Islam Negeri Sumatera Utara, Indonesia

E-mail: didiksantoso@uinsu.ac.id

*) Corresponding Author

\begin{abstract}
The study aims at comparing the models of the spiritual intelligence development in learning morals subject implemented in the boarding schools of Raudhatul Hasanah Medan, Prof Dr. Hamka Padang, Darunnajah Jakarta, and AlKamal Blitar. This research used qualitative method. The data collection techniques were observations, interviews, documents, and focused group discussions. The results are (1) Spiritual intelligence is developed through preparatory learning, learning in the class, and outside of the class, (2) There are four similarities that are preparation of teaching, learning in the class, connection of learning in the class with outside of the class, and the systematic planning between learning in and out of the classroom, (3) There are six differences in the separation of male and female students in classroom learning, as well as separation of learning activities outside of the classroom, the role of teachers in classroom learning, the use of applications to monitor classroom and outside the classroom, management of learning outside the classroom, and the implementation of learning in and out of the classroom (4) The causes of the similarities and differences are the initial background of the boarding schools' founding, the founders' point of view, the boarding schools' developmental process, the management system, and the influence of stakeholder policy.
\end{abstract}

Keywords: Spiritual Intelligence, Learning Morals Subject, Boarding Schools

\section{PENDAHULUAN}

7 lujuan pembelajaran akidah akhlak pada kurikulum 2013 adalah: (1) Agar peserta didik memiliki pengetahuan, penghayatan, dan keyakinan yang benar terhadap hal-hal yang harus diimani, sehingga dalam bersikap dan bertingkah-laku sehari-hari berdasarkan Alqur'an dan Hadits, (2) Agar siswa memiliki pengetahuan, penghayatan, dan keinginan yang kuat untuk mengamalkan akhlak yang baik dan berusaha sekuat tenaga untuk meninggalkan akhlak yang buruk, baik dalam hubungannya dengan Allah SWT, diri sendiri, antar manusia maupun hubungannya dengan alam lingkungan.
Akan tetapi, tujuan di atas belum tercapai sepenuhnya karena masih banyak siswa yang belum menghayati dan mengamalkan pelajaran akidah akhlak. Hal ini dapat dibuktikan banyaknya tingkah laku yang tidak sesuai dengan nilai-nilai akidah akhlak seperti melawan guru, melawan orang tua, berbohong, suka menceritakan orang lain, sampai pada tawuran di dalam dan di luar pesantren. Sebagaimana yang diungkapkan oleh Suryawati (2016) bahwa pembelajaran akidah akhlak bukan hanya mengajarkan pengetahuan tentang agama saja, akan tetapi bagaimana mengarahkan peserta didik agar memiliki kualitas iman, takwa dan akhlak mulia. Maka tantangan yang dihadapi adalah pada pengimplementasiannya. 
Banyak faktor yang menyebabkan masalah tersebut yaitu faktor internal dan eksternal. Faktor internal yang mempengaruhi rendahnya pengamalan nilainilai akidah akhlak adalah pemahaman yang kurang komprehensif mengenai akidah akhlak, cara belajar akidah akhlak yang kurang optimal, kepribadian siswa, minat belajar yang rendah, motivasi belajar yang kurang, dan sebagainya. Sedangkan faktor eksternal yang menyebabkan kurangnya pengamalan nilai-nilai akidah akhlak antara lain pengaruh lingkungan, orang tua, guru, materi pelajaran, media, termasuk model pengembangan pembelajaran akidah akhlak yang dilaksanakan oleh guru, ditambah lagi tantangan di zaman teknologi informasi yang hampir di semua sisi kehidupan harus dengan digitalisasi. Perlu diakui bersama, bahwa era digitalisasi sangat berdampak pada aspek moral spiritual anak. Sisi moral spiritual anak terabaikan, karena ambisi keberhasilan pendidikan yang selama ini hanya terfokus pada pengembangan kemampuan berpikir secara materialistikpositifistik semata dan harus berorientasi pada dunia kerja. Pengembangan kemampuan berpikir yang mengedepankan kecerdasan intelektual yang cenderung pada penguasaan materi tanpa adanya penghayatan terhadap nilai yang ada di balik sebuah ilmu dan pengetahuan (Yuliyatun, 2013).

Sejatinya, tujuan pendidikan bukan sekedar membuat anak dapat bekerja setelah lulus, akan tetapi lebih mulia dari itu adalah agar anak mampu beradaptasi terhadap lingkungannya sehingga menciptakan kelestarian, keharmonisan dan kebersamaan dalam kehidupan. Dengan demikian, akhlak bukan hanya mengajarkan pengetahuan tentang agama akan tetapi bagaimana membentuk kepribadian siswa agar memiliki keimanan dan ketakwaan yang kuat dan kehidupannya senantiasa dihiasi dengan akhlak yang mulia di manapun dan dalam kondisi apapun. Untuk itu, pembelajaran akidah akhlak harus terus dikembangkan sesuai dengan kebutuhan dan tantangan zaman.

Model pengembangan pembelajaran akidah akhlak yang dilakukan oleh guru saat ini masih cenderung menekankan penguasaan pengetahuan. Akibatnya siswa merasa terbebani dengan materi akidah akhlak. Dengan demikian, pembelajaran yang dikembangkan oleh guru hanya sebatas penguasaan ilmu tetapi belum sampai pada pengamalan ilmu. Penguasaan ilmu ini cenderung mengasah intelektual siswa sementara pengamalan ilmu membutuhkan pengasahan kecerdasan emosional dan pengasahan kecerdasan spiritual.

Kecerdasan spiritual merupakan sasaran utama (the ultimate goal) dalam pembelajaran di samping kecerdasan intelektual dan emosional. Sebab, kecerdasan spiritual yang baik dapat memunculkan kesadaran seseorang untuk mengamalkan ilmu yang diajarkan. Ilmu yang diajarkan tidak akan diamalkan bila seseorang belum memiliki kesadaran untuk mengamalkannya. Dengan kata lain, cerdas intelektual dan emosionalnya belum tentu cerdas spiritualnya. Bila seseorang hanya mendapatkan ilmu pengetahuan saja tetapi tidak digunakan maka berakibat pada munculnya perilaku menyimpang. Artinya, ia mengetahui hukum Islam tetapi ia tidak mengamalkan atau bahkan melanggar hukum yang dilakukannya secara sengaja dan sadar.

Sebagaimana hasil penelitian Damayanti \& Solihin (2018) mengatakan bahwa mengembangkan kecerdasan spiritual anak perlu dilakukan sejak dini, agar anak menjadi manusia yang memiliki kepekaan batin dan jiwa terhadap diri sendiri ataupun orang lain. Penelitiannya menemukan bahwa pengembangan kecerdasan spiritual anak melalui pembelajaran dengan penanaman nilai agama, kognitif, dan sosial - emosional dengan berbagai langkah dan metode yang diterapkan untuk mengembangkan kecerdasan spiritual anak.

Dipertegas dengan tulisan Yuliyatun yang menawarkan pendidikan agama harus diberikan sebagai solusi untuk 
mengembangkan kecerdasan spiritual anak (Yuliyatun, 2013). Akan tetapi, hal ini belum bisa menjawab atau menyelesaikan masalah berkaitan dengan kecerdasan spiritual anak karena pendidikan agama yang diberikan di kelas masih sangat terbatas dan lingkungan sekolah juga belum mampu menciptakan konsep dan nilai-nilai agama selama anak berada di sekolah.Terbukti, fenomena perilaku menyimpang telah dan terus terjadi belakangan ini. Perkelahian antar siswa kerap terjadi. Bahkan perilaku LGBT mulai berkembang dari sekolah/madrasah, bahkan di pesantren yang dikenal dengan tempatnya para santri yang diajarkan ilmu-ilmu agama juga terjadi demikian bahkan ada juga pesantren yang dimasuki narkoba. Pemukulan oleh seorang santri kepada santri lain juga menunjukkan semakin gersangnya pembelajaran yang ada di pesantren. Banyak lagi perilaku menyimpang yang terjadi di pesantren saat ini. Senada dengan hal ini, hasil penelitian Kristianti (2018) juga menunjukkan bentuk-bentuk perilaku menyimpang santri mulai dari tingkat ringan, sedang, dan berat. Perilaku menyimpang kecil seperti: tidak mengikuti kegiatan pondok, berboncengan dengan lawan jenis yang bukan mahromnya, menyepelekan peraturan. Tingkat sedang, seperti: berbohong dalam perizinan dan merokok. Tingkat berat, seperti: mabuk karena minum minuman keras.

Kondisi ini dipertegas oleh Utami melalui penelitiannya bahwa saat ini, kriminalitas yang dilakukan oleh anak-anak yaitu perampokan, perjudian, tawuran antar sekolah, pembunuhan, kecanduan narkoba dan lainnya (Utami, 2015). Kondisi ini disebabkan tidak adanya keseimbangan antara nilai keagamaan dengan perkembangan zaman yang semakin maju. Untuk itu, masalah akhlak atau moral memerlukan upaya maksimal sehingga anak mampu mengatasi hal-hal yang tidak baik.

Berbagai strategi dilaksanakan dan terus dikembangkan dalam meningkatkan kecerdasan spiritual anak seperti penelitian yang dilakukan oleh Ahmad (2016) bahwa strategi pengembangan kecerdasan spiritual dilakukan melalui tiga cara yakni penanaman nilai-nilai Islami meliputi sembilan nilai yaitu sabar, syukur, optimis, tawakal, ikhlas, keberanian, keadilan, jujur, tawadhu'di mana guru merupakan model dalam menerapkan nilai tersebut dan harus dengan pembiasaan dan latihan. Selain itu bisa juga dengan menambahkan kegiatan-kegiatan ataupun pembelajaran lain di luar kelas. Saat ini banyak sekolah dan madrasah menambahkan waktu lebih banyak berada di area sekolah dan madrasah dikarenakan tuntutan orang tua yang belum siap mengontrol anaknya beradaptasi dengan lingkungan.

Sebagaimana penelitian tentang full day school yang maksud pendiriannya adalah untuk mengakomodir berbagai permasalahan yang ada di masyarakat. Para orang tua menginginkan anak mereka mendapatkan pendidikan terbaik dari aspek akademik dan non akademik serta memberikan perlindungan bagi anak dari pergaulan bebas (Astuti, 2013). Akan tetapi, masalah penyimpangan prilaku anak masih terus terjadi bahkan semakin meningkat, untuk itu penelitian tentang model, maupun strategi dalam peningkatan kecerdasan anak harus terus dilakukan, mengingat pesatnya perkembangan dan perubahan yang terjadi saat ini. Oleh karena itu, penelitian ini akan menjawab pertanyaan bagaimana model pengembangan kecerdasan spiritual dalam pembelajaran akhak di pesantren modern Indonesia?

\section{METODE PENELITIAN}

Penelitian ini menggunakan metode penelitian kualitatif fenomenologis. Teknik pengumpulan data yang digunakan adalah pengamatan, wawancara, dokumen, dan focused group discussion. Data dianalisis dengan data condensation, data display, dan verification. Sumber data berasal dari guru mata pelajaran akidah akhlak di Madrasah Aliyah dari empat pesantren modern yakni pesantren Raudhatul Hasanah Medan, Pesantren Terpadu Prof Dr. Hamka Padang, Pesantren Darunnajah Jakarta, dan Pesantren 
Terpadu Al-Kamal Blitar. Keempat pesantren ini dipilih karena termasuk pesantren moderen yang diminati masyarakat di daerahnya. Di samping itu, pesantrenpesantren tersebut memiliki keunikan masing-masing dari segi pelaksanaan pembelajarannya dan masih mengalami masalah dalam menanamkan kecerdasan spiritual dalam pembelajaran akhlak. Untuk membangun keterpercayaan data digunakan teknik triangulasi sumber, metode, dan peneliti.

\section{HASIL DAN PEMBAHASAN Model Pengembangan Kecerdasan Spiritual}

Model pengembangan kecerdasan spiritual yang diimplementasikan dalam pembelajaran akhlak di pesantren moderen dapat dilihat dari persiapan pembelajaran, pembelajaran di kelas, dan pembelajaran di luar kelas. Persiapan pembelajaran merupakan perencanaan yang dibuat oleh guru dalam mengembangkan kecerdasan spiritual. Persiapan pembelajaran seharusnya mengandung prinsip-prinsip antara lain berisi kompetensi pengetahuan, keterampilan, sosial, dan spiritual. Namun kenyataannya, persiapan pembelajaran yang dibuat belum memenuhi kriteria di atas. Guru di pesantren sebagian besar menuliskan persiapan mengajarnya cenderung mengutamakan pemerolehan pengetahuan dan keterampilan. Akan tetapi kompetensi spiritualnya tidak dijabarkan secara eksplisit dan jelas. Sebagian guru telah menuliskan kompetensi spiritual akan tetapi belum terukur secara jelas. Sehingga akan berdampak pada pengejawantahannya dalam proses pembelajaran di kelas dan di luar kelas.

Melalui perencanaan ini diharapkan pengembangan kecerdasan spiritual santri dapat dicapai atau diwujudkan dalam proses pembelajaran. Tentu saja untuk mewujudkan hal ini, ada persyaratan tertentu. Antara lain kompetensi kecerdasan spiritual haruslah diartikan sebagai kemampuan santri dalam memaknai apa yang dipelajari dalam kehidupan. Ukuran mampu memaknai adalah bahwa santri tidak hanya memiliki pengetahuan dan keterampilan akan tetapi mampu menghasilkan karya. Bila santri mampu menghasilkan karya, apalagi karya baru yang bermanfaat bagi dirinya dan orang lain maka hal itu berarti pengetahuan dan keterampilan yang diperoleh mampu direfleksikan dalam bentuk karya nyata santri. Dengan demikian, secara bersamaan ia telah memiliki kecerdasan spiritual. Persiapan mengajar merupakan komponen penting dalam pengembangan kecerdasan spiritual santri sebab dengan persiapan yang optimal maka tujuan mengajar yakni santri mendapatkan kecerdasan spiritual sebagai the ultimate goal dalam pembelajaran dapat tercapai. Kecerdasan spiritual dalam hal ini merupakan kemampuan memaknai hidup. Kemampuan ini dapat diartikan sebagai suatu kemampuan untuk menyelesaikan masalah dan nilai, menempatkan tindakan dan kehidupan pada konteks yang dapat memberi makna yang lebih luas dan kaya serta yang dapat mengukur apakah suatu tindakan atau jalan hidup lebih bermakna dari yang lain (Morgan, 2001).

Sesuai dengan data yang diperoleh, guru menyatakan beberapa prinsip pembelajaran antara lain berkenaan dengan tujuan pembelajaran, pengertian cerdas, dan pembelajaran yang sukses. Tujuan pembelajaran akhlak menurut guru adalah untuk memperkuat iman, Islam dan ihsan. Dengan demikian persiapan pembelajaran haruslah berisi tentang materi, metode, media yang mampu memperkuat iman santri. Iman yang kuat akan berdampak pada pengamalan keislamannya. Pengamalan keislaman yang benar akan menghasilkan buah berupa ihsan yakni ketajaman spiritualitas santri.

Hal ini terungkap dari hasil wawancara dengan guru akhlak sebagai berikut: "Yang pertama tauhid itu adalah dasar agama jadinya pondasi pertama, baru syariat setelah itu ihsan. Karena tauhid juga tidak bisa berdiri sendiri harus dibarengin dengan syariat setelah dia tidak ada Tuhan selain 
Allah. Pengertian ini harus diperindah itulah dalam judul ihsan atau akhlak tadi. Jadi, iman tambah islam itu hasilnya akhlak. Jadi, yang pertama tadi itu pondasi yang kedua, akan membuat pribadi seseorang itu menjadi lebih baik karena dia terbiasa patuh kepada yang tak tampak apalagi yang nampak, yang ketiga jalan menuju akhlak tadi”. Berdasarkan data ini dapat disimpulkan bahwa seorang santri harus mampu mengambil manfaat dari apa yang dilihat, didengar, dan dirasakan sehingga terbentuk akhlak yang baik.

Berikutnya santri yang berhasil apabila ia mendapatkan ruh dari pembelajaran yakni ruh mudarris, ruh metode, ruh materi, dan ruhnya media. Ruh mudarris berarti santri mampu mengambil berkah dari sang guru. Tentang hal ini, salah seorang guru menyatakan "Memang tingkat kemampuan beda beda apalagi kalau kita masuk misalnya kita skillnya agak ke bawah maka yang pertama ada dalam istilah tarbiyah kita itu atthoriqha metode itu lebih penting dari pada materi. Terkadang orang itu fokus kepada materi. Walaupun kadang kadang kita naik turun, lelah, kadang sakit. Tapi tetap metode itu lebih penting dari materi. Setelah itu ada lanjutannya Almuddaris Almufhaqiqhah sang pendidik itu lebih penting dari metode. Jadi metode penilaian materi. Jadi mudarrisnya lebih penting daripada metodenya, yang terakhir ruhulmuddaris itu lebih penting dari muddarisnya jadi ruhnya seorang pendidik itu lebih penting dari mudarris itu sendiri”.

Berdasarkan data di atas dapat disimpulkan bahwa persiapan mengajar yang dibuat oleh guru pada pesantren yang diteliti belum secara eksplisit dinyatakan dalam persiapan mengajar. Bahkan persiapan pembelajaran kering dengan nilai-nilai kecerdasan spiritual. Hal ini berakibat pada penanaman kecerdasan spiritual dalam proses pembelajaran.

Selain dari persiapan pembelajaran, kecerdasan spiritual dalam pembelajaran akhlak di pesantren modern di Indonesia juga dikembangkan melalui pembelajaran di kelas. Adapun kecerdasan spiritual dikembangkan oleh pesantren melalui tahapan: membuka, brainstorming, menguraikan materi (definisi, jenis, dalil, cara, mufrodat), membuat ringkasan, evaluasi (cek pemahaman), dan menutup (hamdalah dan salam). Dalam membuka pembelajaran, guru memulainya dengan cara mengucapkan salam dan mengabsen santri. Hal ini dibuktikan dengan data yang dikemukakan oleh salah seorang berikut: "Masuk salam, kemudian beliau absen nah setelah absen kita pasti buka buku. Setelah itu kita ada mengartikan satu satu kalimat seperti biasa. Beliau itu menjelaskannya seperti bercerita lebih kepengalamannya, cerita biasanya."

Setelah mengucapkan salam dan mengabsen, guru melakukan aktivitas brainstorming. Bentuk brainstorming juga bervariasi. Ada yang memberitahukan inti sari dari judul (khulasoh) atau memberi beberapa pertanyaan apakah santri memiliki background knowledge atau skemata tentang materi yang sedang dipelajari. Hal ini dinyatakan oleh salah seorang guru: "Yang pertama kami memberikan kosa kata atau kalau di dalam bahasa Arab namanya mufradat. Karena di dalam buku ini kami memakai bahasa Arab. Pasti ada disana kosa kata yang susah dipahami. Atau mufrodatnya yang tidak diketahui oleh santri. Jadi supaya memudahkan mereka untuk membantu mereka Lalu kemudian memberikan intisari dari pada judul tertentu. Jadi di antara judul itu, kami keluarkan intisarinya atau kami sebut dengan khulasoh. Jadi ada khulasohnya supaya santri mengetahui oh ini adalah inti dari pada judul yang kami pelajari hari ini."

Brainstorming juga dilakukan guru dengan cara mengingatkan kembali apa yang telah dipelajari oleh santri sebelumnya. Hal ini dilakukan dengan cara guru mengajukan pertanyaan kepada santri, lalu santri yang bisa menjawab boleh memberi jawaban terhadap pertanyaan guru. Paparan ini dibuktikan dari paparan santri "Mukhadimah seperti mengucapkan Alhamdulillah, siap itu 
nanti ustad nanyak mengingat pelajaran yang kemarin. Kalo masih ingat kadang menjawab ustad sambil mendengarkan".

Pada proses penyampaian materi pelajaran, guru memiliki filosofi tentang pendidikan di pesantren yakni dengan membedakan antara tarbiyah dengan taklim. Tarbiyah dimaknai sebagai pendidikan dan taklim sebagai pengajaran. Artinya guru di pesantren membedakan antara aksi mendidik dan aksi mengajar. Mendidik diartikan tidak hanya sekedar menyampaikan ilmu tetapi menyampaikan nilai-nilai kehidupan. Sedangkan mengajar diartikan terbatas pada penyampaian pengetahuan tentang pelajaran yang diberikan kepada santri. Berkaitan dengan hal ini, salah seorang guru mengatakan: "karena di pesantren ini yang kita utamakan, atau yang kita inginkan dari pada santri. Adalah tarbiyah, karena tarbiyah itukan pendidikan, kemudian ada taklim, sedangkan taklim itukan pengajaran".

Kesuksesan

pendidikan dan

pembelajaran bagi guru pesantren adalah tidak terbatas pada nilai rapot atau ijazah yang tinggi. Akan tetapi diukur dari keberkahan ilmu yang diperoleh yakni keridhoan guru. Sebagaimana wawancara dengan guru mengatakan "Bila gurumu ridho maka Allah ridho. Itulah yang disebut dengan kesuksesan". Prinsip ini diperkuat dengan pernyataan lanjutan dari guru tersebut yakni "Bahwa guru berperan sebagai fasilitator untuk membuat santri pintar bukan untuk memintarkan santri". Artinya guru hanya sekedar membantu santri untuk menjadi pintar. Tugas pendidik adalah menyampaikan mana yang baik mana yang buruk bukan membuat seseorang itu pintar, dan setelah pintar atau tidaknya itu tergantung dari anak anaknya sendiri. Maka yang penting muddaris itu datang dengan ruh, sehingga ruhnya itu bisa ditransfer ke setiap anak.

Berkaitan dengan evaluasi pembelajaran dalam mengembangkan kecerdasan spiritual santri menunjukkan bahwa evaluasi yang digunakan belum pada tingkat untuk mengembangkan kecerdasan spiritual santri. Padahal evaluasi adalah suatu langkah pembelajaran bukan hanya untuk mengukur seberapa besar penguasaan santri tentang materi yang diajarkan oleh guru tetapi juga aspek sosial dan spiritual santri juga harus diperhatikan. Evaluasi dapat dilakukan guru baik secara lisan maupun tulisan termasuk untuk mengetahui apakah santri sudah atau belum paham tentang apa yang sedang dipelajari.

Untuk melakukan evaluasi ini, guru bertanya kepada santri secara terbuka untuk semua santri. Di samping dalam bentuk pertanyaan terbuka, guru juga menggunakan pertanyaan berupa soal yang sudah ada di dalam buku yang dipelajari santri. Soal tersebut tertulis pada akhir materi yang dipelajari santri. Bila semua pertanyaan yang tertulis itu sudah dapat dijawab dengan benar oleh santri, maka santri sudah dianggap memahami dan menguasai materi yang diajarkan.

Langkah terakhir model pengembangan kecerdasan spiritual dalam pembelajaran adalah menutup pelajaran. Untuk menutup pelajaran, guru menggunakan ungkapan Assalamu'alaikum Warahmatullahi Wabarakatuh. Sebagian guru menutup pelajaran dengan membaca do'a setelah belajar sebelum mengucapkan salam. Hal ini dapat diketahui dari hasil pengamatan terhadap guru yang mengajar tentang akhlak yang menunjukkan bahwa : "Guru menutup pembelajaran dengan salam dan langsung keluar kelas. Data ini diperkuat dengan pernyataan santri: "Ya pas ada bel itu ya kalau mungkin babnya belum selesai mungkin kita akan lanjutkan di pertemuan selanjutnya, setelah itu berdoa setelah belajar. Setelah itu salam, baru itu keluar". Ini bermakna bahwa sebelum salam, pembelajaran juga ditutup dengan doa setelah belajar. Memang tidak semua guru menutup pelajaran dengan berdoa.

Berdasarkan data di atas, dapat disimpulkan bahwa pembelajaran di kelas kurang produktif. Pembelajaran tidak produktif adalah pembelajaran yang tidak 
menghasilkan karya baik karya hasil modifikasi maupun karya baru. Pembelajaran hanya sekedar menceritakan ilmu tetapi tidak dapat memaknai ilmu. Ibarat santri belajar membuat radio. Mereka bisa menyebutkan unsur-unsur radio tetapi tidak bisa membuat radio. Dengan kata lain kecerdasan spiritual santri belum terasah dengan baik.

Model pengembangan kecerdasan spiritual yang dilakukan dalam pembelajaran di luar kelas mencakup kegiatan pengasuhan, kegiatan di masjid, kegiatan Badan Usaha Milik Pesantren (BUMP), kegiatan ekstrakurikuler, dan kegiatan asrama. Kegiatan pengasuhan adalah akivitas rutin untuk mengembangkan kecerdasan spiritual para santri. Kegiatan rutin tersebut terdiri dari kegiatan harian, mingguan, bulanan, dan tahunan. Adapun rekapitulasi kegiatan yang dilaksanakan santri dapat dilihat pada tabel 1 berikut:

Tabel 1. Rekapitulasi Kegiatan Pengasuhan

\begin{tabular}{|c|c|c|c|}
\hline \multicolumn{4}{|c|}{ Kegiatan } \\
\hline Harian & Mingguan & Bulanan & Tahunan \\
\hline 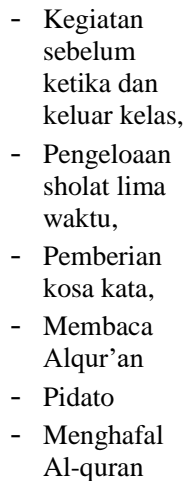 & $\begin{array}{l}\text { - Senam pagi } \\
\text { bersama } \\
\text { - Lari pagi } \\
\text { - Puasa senin- } \\
\text { kamis, } \\
\text { - Kegiatan } \\
\text { pramuka } \\
\text { - Pencak silat }\end{array}$ & 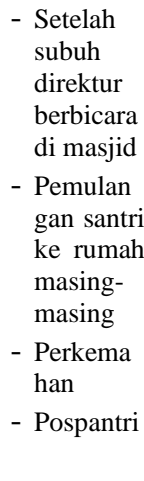 & $\begin{array}{ll}- & \text { Ospek } \\
- & \text { Serah } \\
& \text { terima } \\
& \text { jabatan } \\
- & \text { Lomba } \\
& \text { shalawa } \\
& \text { tan, } \\
- & \text { Lomba } \\
& \text { memasa } \\
& \text { k, } \\
\text { - } & \text { Ujian } \\
\text { tahfiz }\end{array}$ \\
\hline
\end{tabular}

Kegiatan masjid merupakan salah satu aktivitas santri yang dilaksanakan untuk mengembangkan kecerdasan spiritual yang diadakan di wilayah masjid berbentuk halaqoh, ceramah, baca alqur'an, sholat berjama'ah, berdoa, dan zikir. Adapun kegiatan di mesjid yang dilaksanakan santri dapat dilihat pada tabel 2 berikut:

Tabel 2. Rekapitulasi Kegiatan Mesjid

\begin{tabular}{|c|c|c|c|}
\hline \multicolumn{4}{|c|}{ Kegiatan } \\
\hline Halaqoh & Ceramah & $\begin{array}{l}\text { Membaca, } \\
\text { MenghafalAl- } \\
\text { qur'an }\end{array}$ & $\begin{array}{l}\text { Sholat } \\
\text { berjama'ah }\end{array}$ \\
\hline $\begin{array}{l}\text { Dilaksanaka } \\
\mathrm{n} \text { dengan } \\
\text { cara duduk } \\
\text { berkeliling } \\
\text { di lantai dan } \\
\text { cenderung }\end{array}$ & \begin{tabular}{l}
\multicolumn{2}{l}{ Dilakukan } \\
secara rutin \\
di masjid \\
sebelum atau \\
setelah sholat \\
5 waktu. Hal
\end{tabular} & $\begin{array}{l}\text { Dilaksanakan } \\
\text { ba'da magrib } \\
\text { sampai } \\
\text { menjelang } \\
\text { sholat Isya, }\end{array}$ & $\begin{array}{l}\text { Dilaksanakan } \\
\text { setiap } 5 \text { waktu } \\
\text { dan } \\
\text { sholat jum'at. } \\
\text { ada pesantren } \\
\text { yang sudah }\end{array}$ \\
\hline
\end{tabular}

\begin{tabular}{|c|c|c|c|}
\hline \multicolumn{4}{|c|}{ Kegiatan } \\
\hline Halaqoh & Ceramah & $\begin{array}{l}\text { Membaca, } \\
\text { MenghafalAl- } \\
\text { qur'an }\end{array}$ & $\begin{array}{l}\text { Sholat } \\
\text { berjama'ah }\end{array}$ \\
\hline $\begin{array}{l}\text { bersifat } \\
\text { informal } \\
\text { terutama } \\
\text { untuk } \\
\text { mempelajari } \\
\text { kitab klasik }\end{array}$ & $\begin{array}{l}\text { ini } \\
\text { dimaksudkan } \\
\text { lebih } \\
\text { menyebarluas } \\
\text { kan ilmu dan } \\
\text { memantapka } \\
\text { n ilmu } \\
\text { yang } \\
\text { diajarkan di } \\
\text { dalam kelas. }\end{array}$ & & $\begin{array}{l}\text { menditeksi } \\
\text { santrinya } \\
\text { berjama'ah di } \\
\text { masjid melalui } \\
\text { finger print }\end{array}$ \\
\hline
\end{tabular}

Kegiatan badan usaha milik pesantren (BUMP) merupakan salah satu usaha pesantren dalam mengembangkan kecerdasan spiritual santri. Melalui badan usaha ini para santri dilibatkan untuk memaknai hidup. Bagaimana kehidupan nyata dalam masyarakat sesungguhnya. Sehingga santri paham betul arti kehidupan. Oleh karena itu santri dilibatkan dalam pelaksanaan BUMP. Rekapitulasi kegiatan BUMP yang dilaksanakan di pesantren dapat dilihat pada tabel 3 berikut:

Tabel 3.Rekapitulasi Kegiatan BUMP

\begin{tabular}{|l|l|}
\hline \multicolumn{1}{|c|}{ Jenis } & \multicolumn{1}{c|}{ Tujuan } \\
\hline - $\begin{array}{l}\text { Pelaksanaanya dari } \\
\text { tingkat guru sampai ke } \\
\text { santri }\end{array}$ & $\begin{array}{l}\text { Guru setiap saat memantau } \\
\text { perkembangan kecerdasan } \\
\text { spiritual santri }\end{array}$ \\
- Santri yang ditugaskan \\
$\begin{array}{l}\text { disumpah terlebih } \\
\text { dahulu }\end{array}$ & $\begin{array}{l}\text { Menjaga amanah dalam } \\
\text { menjalankan tugasnya. }\end{array}$ \\
& Diharapkan juga belajar untuk \\
& jujur dan ikhlas \\
\hline
\end{tabular}

Buzan menyebutkan bahwa ciri-ciri orang yang mempunyai kecerdasan spiritual salah satunya adalah turut merasa memikul sebuah misi mulia, hidup seseorang akan terasa jauh lebih bermakna apabila ia turut merasa memikul sebuah misi mulia kemudian merasa terhubung dengan sumber kekuatan (Azzet, 2010). Melalui kegiatan ekstrakurikuler ini, santri menjadi optimal pengembangan kecerdasan spiritualnya karena santri secara terus menerus mendapatkan latihan berupa praktek langsung secara berulang-ulang sampai mahir. Adapun kegiatan ekstrakurikuler dalam bentuk olahraga dan kegiatan kesenian. Kegiatan ekstrakurikuler yang dilaksanakan dapat dilihat pada tabel 4 berikut:

Tabel 4. Rekapitulasi Kegiatan BUMP

\begin{tabular}{|c|c|c|}
\hline Olahraga & Kesenian & Tujuan \\
\hline - Sepakbola & & $\begin{array}{ll}\text { Menjadikan } \\
\text { santri }\end{array}$ \\
\hline
\end{tabular}




\begin{tabular}{|l|l|l|}
\hline Olahraga & Kesenian & Tujuan \\
\hline - Bola Basket & Tilawah & memiliki fisik \\
- Badminton & Puisi & yang sehat dan \\
- Beladiri & Pidato & jiwa seni yang \\
- Dll & & \\
\hline
\end{tabular}

Kegiatan asrama merupakan aktivitas santri di luar kelas dalam mengembangkan kecerdasan spiritual, dalam bentuk pembersihan kamar santri dari benda-benda syirik, membangunkan santri dengan lemah lembut, solat tahajjud, solat berjamaah, sarapan pagi, belajar di kelas, gotong royong, memberikan hukuman yang mendidik. Kegiatan ekstrakurikuler yang dilaksanakan dapat dilihat pada tabel 5 berikut:

\section{Tabel 5. Rekapitulasi Kegiatan BUMP}

\begin{tabular}{|c|c|}
\hline Kegiatan & Pelaks \\
\hline $\begin{array}{l}\text { - Pembersihan kamar } \\
\text { santri dari benda-benda } \\
\text { syirik }\end{array}$ & $\begin{array}{l}\text { Dua kali dalam seminggu, } \\
\text { sebagian besar berasal dari } \\
\text { pedesaan. }\end{array}$ \\
\hline $\begin{array}{l}\text { Membangunkan santri } \\
\text { untuk sholat tahajjud }\end{array}$ & $\begin{array}{l}\text { Setiap hari pukul } 04.00 \text { dengan } \\
\text { lemah lembut }\end{array}$ \\
\hline - Sarapan pagi & - Dengan cara antri \\
\hline - Gotong royong & - Dilaksanakan setiap minggu \\
\hline $\begin{array}{l}\text { - Memberikan hukuman } \\
\text { mendidik }\end{array}$ & \begin{tabular}{|l} 
Menulis ayat alquran \\
Nasehat \\
- Dikeluarkan dari pesantren
\end{tabular} \\
\hline
\end{tabular}

Akhirnya model pengembangan

kecerdasan spiritual yang dilakukan pada pesantren modern sesuai dengan konsep pengembangan kecerdasan spiritual, sebagaimana yang diungkapkan oleh Zohar dan Marshal (2002) mengemukakan enam jalan untuk mengembangkan kecerdasan spiritual di sekolah yaitu melalui pemberian tugas, pengasuhan, pengetahuan, perubahan pribadi (kreatifitas), persaudaraan, kepemimpinan yang penuh pengabdian (Utami L. H., 2015). Harapan yang diinginkan dari pengembangan kecerdasan spiritual ini adalah santri memiliki akhlak yang sempurna, serta mampu beradaptasi, dan mampu memecahkan masalah hidup dan kehidupannya.

Orang yang mempunyai kecerdasan spiritual memiliki karakteristik yaitu kapasitas diri untuk bersikap fleksibel, tingkat kesadaran diri (self-awareness) yang tinggi, kapasitas diri untuk menghadapi dan memanfaatkan penderitaan (suffering), kemampuan menghadapi rasa takut, kualitas hidup yang terinspirasi dengan visi dan nilai, enggan menyebabkan kerugian yang tidak perlu (unnecessary harm), memiliki cara pandang yang holistik, memiliki kecenderungan untuk melihat keterkaitan diantara sesuatu yang berbeda, cenderung bertanya "mengapa" atau "bagaimana jika" untuk mencari jawaban-jawaban yang benar, memiliki kemudahan untuk bekerja melawan kontraversi (Marshall \& Zohar, 2007).

Kecerdasan spiritual sangat erat kaitannya dengan kejiwaan. Oleh karena itu, jiwa anak harus terus diisi dengan nilai-nilai kebenaran dan kebaikan, dan harus dapat terimplementasi dalam ritual keagamaan dan ibadah. Hal inilah yang terus dilakukan di dalam pembelajaran di pesantren, yang membedakannya dengan sekolah maupun madrasah yang tidak memiliki sistem asrama. Santri didik untuk mengenal nilanilai kebenaran dan kebaikan, dan secara langsung dan terus menerus mengamalkannya dalam kesehariannya. Akan tetapi, kelemahan yang dialami selama ini adalah kegiatan pembelajaran di kelas belum maksimal dalam mengembangkan kecerdasan spiritual santri sedangkan pembelajaran di luar kelas lebih banyak mengembangkan kecerdasan ini.

\section{Persamaan \& Perbedaan Pengembangan \\ Kecerdasan Spritual di Pesantren Modern Indonesia}

Terdapat empat persamaan yang dilakukan pesantren dalam mengembangkan kecerdasan spiritual santri yakni ditinjau dari persiapan mengajar, pembelajaran di kelas, koneksitas pembelajaran di kelas dengan di luar kelas, dan perancangan sistematik antara pembelajaran di dalam dan di luar kelas. Keempat pesantren yang diteliti dalam hal persiapan mengajar belum secara eksplisit dinyatakan dalam persiapan mengajar terlihat dari rencana pembelajaran yang dibuat belum ada memasukkan nilai-nilai yang mendukung dalam mengembangkan kecerdasan spiritual. Padahal persiapan mengajar ini merupakan komponen penting dalam pengembangan kecerdasan spiritual santri sebab dengan persiapan yang optimal maka tujuan mengajar yakni santri 
mendapatkan kecerdasan spiritual sebagai the ultimate goal dalam pembelajaran dapat tercapai.

Pengembangan kecerdasan spiritual dalam pembelajaran di kelas yang dilaksanakan masih lebih dominan mengasah kecerdasan otak melalui penyampaian pengetahuan. Mulai dari membuka pelajaran sampai menutup bahkan memberi evaluasi, kebanyakan berisi materi pengetahuan. Guru lebih dominan mengembangkan materi atau kecerdasan otak dari pada pengembangan kecerdasan spiritual santri. Seharusnya pembelajaran yang berlangsung hendaknya dapat membantu santri dalam mengembangkan kecerdasan spritualnya.

Dilihat dari sudut koneksitas antara pembelajaran di kelas dan diluar kelas, pengembangan kecerdasan spiritual di keempat pesantren belum dikaitkan secara sengaja. Sebagian besar program pembelajaran di kelas maupun di luar kelas berjalan sendiri-sendiri. Hal ini dinyatakan oleh salah seorang guru yang menunjukkan seakan-akan pembelajaran di kelas sangat terbatas dan kurang dominan dalam mengembangkan kecerdasan spiritual santri. Sementara pembelajaran di luar kelas dianggap lebih berpengaruh. Guru tersebut menyatakan: "Pendidikan kita itu tidak hanya di kelas karena kita di sini 24 jam. Bahkan kalau dihitung hitung lebih banyak di luar kelas, maka kegiatan belajar di luar kelaslah yang sangat menentukan. Jadi, dapat disimpulkan bahwa dalam mengembangkan kecerdasan spiritual belum adanya koneksi yang jelas dan komprehensif antara pembelajaran di kelas dengan pembelajaran di luar kelas.

Pengembangan kecerdasan spiritual dalam pembelajaran di dalam dan di luar kelas belum dirancang secara sistematis. Hal ini dapat dilihat dari sering terputusnya hubungan antara materi yang diberikan di dalam kelas dengan di luar kelas. Belum ada hubungan yang sistematis antara keduanya. Bahkan kegiatan pembelajaran di kelas terkesan terpisah dengan pembelajaran di luar kelas. Artinya belum ada perancangan materi dan kegiatan yang sistematik antara pembelajaran di dalam dan di luar kelas.

Selanjutnya terdapat enam perbedaam dalam pengembangan kecerdasan spiritual dalam pembelajaran tentang akhlak yakni pemisahan santri laki-laki dan perempuan dalam proses pembelajaran di kelas, pemisahan kegiatan pembelajaran di luar kelas antara santri laki-laki dan perempuan, peran guru dalam pembelajaran di kelas, penggunaan aplikasi dalam memonitor pembelajaran di kelas dan di luar kelas, pengelolaan pembelajaran di luar kelas, dan pelaksanaan pembelajaran di dalam dan di luar kelas.

Pemisahan santri laki-laki dan perempuan dalam proses pembelajaran di kelas terdapat pada dua pesantren. Kedua pesantren ini hampir memiliki latar belakang yang sama yaitu bahwa keduanya merupakan pesantren wakaf dan tidak mau menghilangkan ciri pesantren tradisional maka pesantren ini tetap menggunakan kurikulum pesantren. Akan tetapi dua pesantren yang lain dalam proses pembelajaran tidak memisahkan santri lakilaki dan perempuan. Kedua pesantren ini memadukan antara pengetahuan umum dengan pengetahuan agama. Jadi, para pendirinya berasal dari praktisi pendidikan umum dan bukan pesantren tradisional tetapi lembaga pendidikan moderen. Maka pesantrennya disebut dengan pesantren terpadu. Pesantren model ini melakukan kegiatan pagi di sekolah sampai siang. Sedangkan dari sore sampai malam santri melakukan kegiatan di pesantren.

Pemisahan kegiatan pembelajaran di luar kelas antara santri laki-laki dan perempuan terjadi di dua pesantren yang masih mempertahankan kebiasaan tradisional. Artinya santri laki-laki memiliki tempat sendiri untuk belajar dan begitu juga santri perempuan. Pesantren yang lain masih memiliki satu pusat administrasi sedangkan yang satu lagi sedang proses membangun pusat administrasi khusus santriwan dan khusus santriwati. Tetapi guru yang mengajar ada yang laki-laki dan ada yang 
perempuan. Sementara dua pesantren yang lain kegiatan belajarnya sama dengan sekolah umum yakni santriwan dan santriwati bergabung dalam satu kelas. Pesantren yang satu dikelola oleh satu nama lembaga dan yang satu lagi dikelola oleh dua lembaga yakni sekolah Madrasah Aliyah Negeri dan pesantren.

Dipandang dari peran guru dalam pembelajaran di kelas, keempat pesantren berbeda-beda walaupun ada yang sama. Pada tiga pesantren sebagian besar guru berperan sebagai kontrol yakni pembelajaran masih berpusat pada guru (teacher-centered). Artinya guru jauh lebih aktif dari santri. Sedangkan di satu pesantren guru berperan ada sebagai kontrol dan ada sebagai fasilitator atau student-centered.

Dari segi penggunaan aplikasi dalam pembelajaran di dalam dan di luar kelas, terdapat satu pesantren yang terletak di ibu kota negara sudah mengikuti perkembangan teknologi baru dimana pesantren yang telah menggunakan aplikasi untuk memonitor pembelajaran di kelas dan di luar kelas. Sementara tiga pesantren yang lain masih belum menggunakan aplikasi.

Dalam hal pengelolaan pembelajaran di luar kelas, ada dua pesantren menugaskan santri senior. Sedangkan guru hanya sebagai pengawas. Pada dua pesantren yang lain pengelolaan pembelajaran di luar kelas langsung dilakukan oleh guru yang disebut dengan wali kamar. Pada pelaksanaan pembelajaran di dalam dan di luar kelas, ada tiga pesantren dilaksanakan oleh satu lembaga. Sedangkan satu pesantren dilaksanakan oleh dua lembaga yakni sekolah dan pesantren.

Dari temuan ini dapat disimpulkan bahwa persamaan dan perbedaan pengembangan kecerdasan spiritual dapat membedakan kemajuan pesantren. Bila penanaman kecerdasan spiritualnya dalam pembelajaran lebih baik maka pesantren tersebut akan jauh lebih maju. Di samping itu, sistem pengelolaan pesantren juga dapat diketahui dalam rangka untuk melakukan perbaikan. Dengan diketahuinya persamaan dan perbedaan dapat juga diprediksi sumbangsih pesantren terhadap penyelesaian permasalahan bangsa khususnya kekeringan spiritual yang telah dan sedang melanda hampir di setiap sisi kehidupan berbangsa dan bernegara.

\section{Penyebab Terjadinya Persamaan dan Perbedaan}

Terjadinya persamaan dan perbedaan pengembangan kecerdasan spiritual dalam pembelajaran akhlak di keempat pesantren disebabkan paling tidak empat hal yakni: Awal mula berdirinya pesantren, pandangan hidup para pendiri, proses perkembangan pesantren, sistem pengelolaan pesantren, dan pengaruh kebijakan stakeholder. Masa awal berdirinya pesantren menjadi penyebab adanya persamaan dan perbedaan pengembangan kecerdasan spiritual. Ada pesantren yang pada awalnya adalah wakaf dari pendiri dan masyarakat sehingga pengembangan kecerdasan spiritualnya didasarkan pada pola pengelolaan kecerdasan spiritual dengan sistem terbuka. Artinya orang yang memiliki kompetensi yang ditugaskan untuk mengelola pesantren.

Para pengelola pesantren ini memilih pengelolaan pesantren tradisional dikombinasikan dengan pesantren moderen. Sehingga pesantren ini mengelompokkan santrinya dengan cara memisahkan pembelajaran untuk santriwan dan santriwati. Sementara, ada juga pesantren yang awalnya didirikan praktisi pendidikan dari perguruan tinggi umum dan agama serta dari mantan anggota DPR dan pengusaha. Dalam pembelajaran, pesantren ini masih menggabungkan santriwan dan santriwati dalam pelaksanaan pembelajaran.

Pandangan hidup para pendiri juga menjadi penyebab pola pengembangan kecerdasan spiritual. Pesantren di Jawa Timur khususnya yang menjadi salah satu latar penelitian ini merupakan gabungan antara sekolah negeri dengan pesantren. Santrinya sekolah di Madrasah Aliyah Negeri (MAN) pada siang hari sedangkan pada sore dan malam hari santrinya tinggal dan belajar di pesantren. 
Pada awalnya MAN tersebut menjadi milik pesantren. Akan tetapi, karena pandangan hidup para pendiri, pesantren ini dilepas untuk menjadi negeri dengan pengelolaan masing-masing agar lebih profesional. Namun sampai saat ini walaupun beda pengelolaan tetapi pada pelaksanaannya saling bersinergi. Bahkan siswa-siswi MAN terdiri dari beberapa pesantren yang ada di sekitar sekolah MAN itu. Pagi sampai siang mereka menjadi siswa dan siswi MAN tetapi di sore dan malam hari mereka menjadi santriwan dan santriwati yang tersebar di beberapa pesantren.

Proses perkembangan pesantren dapat juga menjadi penyebab sama dan berbedanya pola pengembangan kecerdasan spiritual. Proses perkembangan pesantren dari pesantren murni kemudian menjadi sekolah tentunya akan mengubah proses pengembangan kecerdasan spiritual. Yang selama ini santri mengikuti pola pesantren tradisional. Dengan berkembangnya pesantren menjadi sekolah Madrasah Aliyah Negeri maka sistem belajarnya menjadi berubah.

Sistem pengelolaan pesantren juga menjadi penyebab adanya persamaan dan perbedaan pola pengembangan kecerdasan spiritual. Satu sistem pengelolaan di bawah satu yayasan akan berbeda dengan sistem pengelolaan di bawah dua lembaga yakni yayasan dan sekolah negeri. Sistem pengelolaan di bawah satu yayasan akan dapat dengan mudah mengelompokkan santriwan dan santriwati pada tempat belajar yang berbeda. Sedangkan pesantren yang pengelolaannya di dua lembaga yakni pesantren dan sekolah terpaksa mereka membuat santriwan dan santriwati belajar dalam satu kelas.

Pengaruh kebijakan stakeholder dapat memberi dampak kepada pola pengembangan kecerdasan spiritual santri. Pesantren wakaf kemudian dirubah menjadi yayasan karena peraturan pemerintah akan berdampak pada kemandirian pesantren dalam melakukan kebijakan. Bila sudah berbentuk yayasan maka akan terikat dengan peraturan pemerintah dalam mengelola pesantren.

Oleh karena itu, alasan mengapa persamaan dan perbedaan pengembangan kecerdasan spiritual itu terjadi dapat diketahui keunggulan dan kelemahan pesantren. Dari informasi ini dapat dibaca suatu keadaan yang menjadi umpan balik bagi praktisi pendidikan untuk segera mengambil tindakan yang diperlukan dalam peningkatan kualitas.

\section{KESIMPULAN DAN REKOMENDASI}

Berdasarkan temuan dan pembahasan di atas dapat disimpulkan bahwa: Pertama, kecerdasan spiritual santri dikembangkan dalam pembelajaran akhlak berbentuk persiapan pembelajaran, pembelajaran di kelas, dan pembelajaran di luar kelas. Kedua, terdapat empat persamaan yang dilakukan pesantren dalam mengembangkan kecerdasan spiritual santri yaitu persiapan mengajar, pembelajaran di kelas, koneksitas pembelajaran di kelas dengan di luar kelas dan perancangan sistematik antara pembelajaran di dalam dan di luar kelas.

Ketiga, terdapat enam perbedaan dalam pengembangan kecerdasan spiritual dalam pembelajaran tentang akhlak yaitu pemisahan santri laki-laki dan perempuan dalam proses pembelajaran di kelas, pemisahan kegiatan pembelajaran di luar kelas antara santri laki-laki dan perempuan, peran guru dalam pembelajaran di kelas, penggunaan aplikasi dalam memonitor pembelajaran di dalam dan di luar kelas, pengelolaan pembelajaran di luar kelas, dan pelaksanaan pembelajaran di dalam dan di luar kelas.

Keempat, penyebab terjadinya persamaan dan perbedaan pengembangan kecerdasan spiritual di keempat pesantren disebabkan oleh 5 faktor yakni: awal mula berdirinya pesantren, pandangan hidup para pendiri, proses perkembangan pesantren, sistem pengelolaan pesantren, dan pengaruh kebijakan stakeholder. 


\section{REFERENSI}

Astuti, M. (2013). Implementasi Program Fullday School Sebagai Usaha Mendorong Perkembangan Sosial Peserta Didik TK Unggulan Al-Ya'lu Kota Malang. Jurnal Kebijakan dan Pengembangan Pendidikan, 1(2), 133140.

Azzet, A. M. (2010). Mengembangkan Kecerdasan Spiritual Bagi Anak. Yogjakarta: Katahati.

Damayanti, U. F., \& Solihin. (2018). Pengembangan Kecerdasan Spiritual Anak Melalui Pembelajaran dengan Penerapan Nilai Agama, Kognitif, dan Sosial-Emosional: Studi Deskriptif Penelitian di Raudhatul Athfal al- Ihsan Cibiru Hilir. Jurnal Syifa Al-Qulub, 2(2), 65-71.

Kristianti, M. W. (2018). Perilaku Menyimpang Kaum Santri (Studi di Lingkungan Pondok Pesantren Nurul Ummahat Kotagede, Yogyakarta. Universitas Islam Negeri Sunan Kalijaga Yogyakarta. Yogyakarta:

Marshall, I., \& Zohar, D. (2007). SQ Kecerdasan Spiritual. Bandung: Mizan Pustaka.

Morgan, A. (2001). Danah Zohar and Ian Marshall: SQ-Spiritual Intelligence, the
Ultimate Intelligence. London: HarperCollins Publishers.

Mulyatiningsih, E. (2018). Pengembangan Model Pembelajaran. Retrieved september $\quad 14, \quad 2019, \quad$ from http://staff.uny.ac.id/sites/default/files

Pendidikan, W. (2018). Tujuan dan Fungsi Pembelajaran Aqidah Akhlaq. Retrieved from http://tujuandanfungsi pembelajaranaqidahakhlaqwawasanpendi dikan.

Suryawati, D. P. (2016). Implementasi Pembelajaran Akidah Akhlak Terhadap Pembentukan Karakter Siswa di MTs. Jurnal Pendidikan Madrasah, 1(2), 309322.

Utami. (2015). Pengembangan Kecerdasan Spiritual Siswa Di SD Islam Tompokersan Lumajang. Psympathic Jurnal Ilmiah Psikologi, 2(1), 63-78.

Utami, L. H. (2015). Pengembangan Kecerdasan Spiritual Siswa di SD Islam Tompokersan lumajang. Psympathic: Jurnal Ilmiah Psikologi, 2(1), 638-669.

Yuliyatun. (2013). Jurnal Konseling Religi, 1(1), 153-172.

Yuliyatun. (2013). Mengembangkan Kecerdasan Spiritual Anak Melalui Pendidikan Agama. Jurnal ThufuLA, 1(1), 153-172.

Article Metadata:

Arlina. Santoso, D. (2020). The Spiritual Intelligence Development Model in Moral Learning in Indonesian Modern Islamic Boarding Schools. Ta'dib, 23 (1), 39-50.

http://dx.doi.org/10.31958/jt.v23i1.1863

Keywords: Spiritual Intelligence, Moral Learning, Boarding School

Coresponding author: Arlina, Universitas Islam Negeri Sumatera Utara, arlina@uinsu.ac.id 